\title{
Coping strategies of Greek students
}

Maria Mpekou Theodoratou*, Dionysios Tafiadis, Vasilios Mpekos,
Maria Euaggelatou, Basiliki Kiritsi, Athanasia Plitsi and Dimitra Pistola

Address: T.E.I. of Patras, Greece

* Corresponding author

from International Society on Brain and Behaviour: 2nd International Congress on Brain and Behaviour

Thessaloniki, Greece. 17-20 November 2005

Published: 28 February 2006

Annals of General Psychiatry 2006, 5(SuppI I):S222 doi:I0.I I86/I744-859X-5-SI-S222

\section{Background}

The present research project aims to examine the coping strategies used by Greek students in five cities of Greece, and different educational systems [Universities (AEI), Technological institutes (ATEI), institutions of occupational formation (IEK)].

\section{Materials and methods}

In this research took part 990 participants recruited from the Greek educational system, among 5 cities of Greece (Athens, Patras, Volos, Larisa, and Kozani), aged from 17 to 25 years of age. The sample was taken in random order. The questionnaire, which was administrated to the 990 students, was the Toulouse Scale about coping, which was created from Tap, Espabes, and Sordes in 1993.

\section{Results}

Statistical analysis of the data revealed that the $99.50 \%$ of questioned students uses in middle extent action strategies, the $95.90 \%$ uses information strategies, and the $95.2 \%$ uses emotional strategies. It also positive that the $1.9 \%$ uses in high extent and the $94.8 \%$ in the middle extent positive strategies. Negative coping strategies are used in the middle extent from the $95.9 \%$ of students.

\section{Discussion}

While the occupational stress is particularly increased in Universities, from the analysis we managed to see that students are using a variety of strategies, such as focus (94.7\%), the social support (94.7\%), withdrawal in low extent $(1.2 \%)$, diversion in middle extent $(95.1 \%)$, controle $(96.1 \%)$, and denial $(94.8 \%)$. Its seams positive, that crushing majority of the participants are able to have stress under control. However, there are statistically differences in accordance with sex, age and the studying school. The counseling probabilities were also discussed.

\section{References}

I. Tap P, Esparbes P, Sordes-Ader F: Stratégies de coping et Personnalisation. Psychologie 1995.

2. Lazarus RS, Folkman S: Stress, Appraisal and coping New York: Springer; 1984.

3. Lazarus RS, Folkman P: The concept of coping 3rd edition. New York: Columbia University Press; 1991.

4. Tap P, Esparbes P, Sordes-Ader F: Presentation I echelle de coping. Les strategie de coping. Journees du labo St. Criq 1993:89-107. 